\title{
EVALUATION OF MORPHOLOGICAL AND KERNEL MICRONUTRIENT TRAITS IN MAIZE LANDRACES
}

\author{
Violeta Andjelković ${ }^{* 1}$, Jelena Mesarović ${ }^{1}$, Mirjana Srebrić ${ }^{1}$, \\ Natalija Kravić1, Vojka Babić ${ }^{1}$, Snežana Mladenović Drinić ${ }^{1}$
}

\begin{abstract}
Maize grains contain high level of carotenoids and tocopherols compared with other cereals. Among carotenoids the $\beta$-carotene has the highest activity and is considered important in breeding programs of biofortified crops. Changes in carotenoids content in the maize grain could be influence of genotype $x$ environment interaction, or effect of existing relationship between the color of the endosperm and the presence of carotenoids. This research was performed to estimate differences in morphological traits, grain content of tocopherols $(\alpha-, \beta+\gamma-, \delta$-), $\beta$-carotene, lutein and zeaxantin in local and introduced populations from Maize Research Institute "Zemun Polje" gene bank. Micronutrient content was detected by using high-performance liquid chromatography (HPLC). Coefficient of variation for morphological traits was less than $10 \%$, except for grain yield per plant which vary about $18,6 \%$. $\alpha$-tocopherol content was in the range from 1.04-8.42 $\mu \mathrm{gg}^{-1}$ $\mathrm{DW}$, and $\beta$-carotene content varied from 0.26 to $7.95 \mu \mathrm{gg}^{-1} \mathrm{DW}$. $\delta$-tocopherol was in significant correlation with number of kernels per row $(\mathrm{r}=0.700 * * *)$, and $\beta+\gamma$-tocopherol was in significant negative correlation with plant and ear height $\left(\mathrm{r}=-0.601^{* * *} ; \mathrm{r}=-0.591^{* *}\right)$. Correlations between morphological traits and $\alpha$-tocopherol were weak and without significance. Kernel color was significantly correlated with the content of zeaxantin $(\mathrm{r}=0,590 * * *)$ and $\beta$-carotene $\left(\mathrm{r}=0,398^{*}\right)$. For biofortification purposes a pool of 11 landraces with increased content of both, $\beta$-carotene and $\alpha$-tocopherol, will be created based on obtained results.
\end{abstract}

Key words: $\beta$-carotene, grain, tocopherol, populations, Zea mays L.

Original Scientific Paper (Originalni naučni rad)

${ }^{1}$ Andjelković V*., Mesarović J., Srebrić M., Kravić N., Babić V., Mladenović Drinić S., Maize Research Institute Zemun Polje, S. Bajića 1, 11185 Belgrade

*e-mail: avioleta@mrizp.rs 


\section{Introduction}

Maize grain contains considerable amounts of carotenoids (Wurtzel, 2004) and has a greater total phenolic content and total antioxidant activity than wheat, oats or rice (Adom and Liu, 2002). Kernel could be of different color, such as white, yellow, orange, purple, black and mixed varieties. In addition to its attractive colors, pigmented maize grain is rich in phytochemicals like phenolic compounds, carotenoids and flavonoids.

Carotenoids and tocopherols typically found in maize include $\alpha$-carotene, $\beta$-carotene, cryptoxanthin, lutein, zeaxanthin, and $\alpha-, \beta-$, and $\gamma$-tocopherols. About 50 carotenoids have pro-vitamin A activity, and the $\beta$-carotene has the highest activity and for this reason, has been considered of high interest in breeding of biofortified crops. According to Harvest Plus project, $15 \mu \mathrm{g} / \mathrm{g}$ of provitamin A carotenoids content is the target value in maize, and half of that is acceptable for the beginning of breeding program (Pixley et al., 2013). For breeding purposes and biofortification improvement in maize, it is necessary to have naturally occurred variability, and the first step is to identify concentration of micronutrient of interest, e.g. carotene, xantophylls, tocopherol etc.

Maize (Zea mays L.) grain is important sources of vitamin $\mathrm{E}$ for food and feed (Rocheford et al., 2002). They exist as a family of four derivatives each $(\alpha-, \beta-, \gamma$ and $\delta)$, which differ in the number and position of methyl substitutions in the chromanol ring. Tocopherols are well recognized as antioxidants in vegetable oils, and their presence increases the stability of lipid membranes, protecting against autoxidation and preventing damage to tissues (Sattler et al., 2004; Traber et al., 2007).

Landraces are dynamic populations of plant with a historical origin, identity, genetically diverse, result of both natural and human selection (Bellon and van Etten, 2013).

In general, cereal landraces and old varieties are among the best sources of phytonutrients accompanied with optimal micronutrient concentrations. Nevertheless, while traits associated with yield and resistance has been the focus of most research, quality traits that are dependent on chemical composition are less studied.

The aim of the present study was to investigate micronutrient content in dark yellow and orange colored kernels of local and introduced maize landraces, in order to create a pool which will be used in biofortification breeding programs.

\section{Material and methods}

In this study 29 accessions with orange kernel (Drinić Mladenović et al., 2016) from Maize Research Institute Zemun Polje (MRIZP) genebank were analyzed for morphological traits, their carotenoid and tocopherol contentand composition. The accessions were multiplied in the experimental field of MRIZP and planted in two rows, with spacing of $0.7 \mathrm{~m}$ between rows and $0.4 \mathrm{~m}$ between hills. Plots were overplanted and thinned to two plants per hill after seedling establishment. Five plants from each row were selfed and the rest ears were allowed to open-pollinate. Following morphological traits were measured on ten randomly chosen plants per plot and averaged: plant height $(\mathrm{PH}-\mathrm{cm})$, ear height $(\mathrm{EH}-\mathrm{cm})$, leaf width (LW-cm), leaf length (LL-cm), number of leaves above the uppermost ear including ear leaf (NoL). Ear leaf length was measured in $\mathrm{cm}$ after pollination; also, the width of the same leaf was measured at the widest point, in $\mathrm{cm}$ (LW, Tollenar et al., 2004). Ear length (EL$\mathrm{cm}$ ), number of rows per ear (NRE) and number of kernels per row (NKR) were measured on 10 open pollinated ears after harvesting. Kernel 
types (Ktyp) and kernel colors (Kcol) were evaluated according to IBPGR descriptors.

Maize grains from selfed ears were milled into flour (particle size less than $500 \mu \mathrm{m}$ ), and used for the analyses of carotenoid and tocopherol content. Standards for carotenoids (lutein, zeaxantin and $\beta$-carotene) and tocopherol $(\alpha-, \gamma+\beta$ and $\gamma)$ were produced by Sigma Aldrich (Germany).

Carotenoid content and composition was determined using high performance liquid chromatography (HPLC), slightly modified method proposed by Rivera and Canela, (2012). Briefly, $0.15 \mathrm{~g}$ of maize flour was extracted twice with $5 \mathrm{~mL}$ of the methanol-ethyl acetate $(6: 4, \mathrm{v} / \mathrm{v})$ for $30 \mathrm{~min}$ at room temperature. After centrifugation (3000 rpm, for $5 \mathrm{~min}$ ), the extracts were evaporated under the stream of nitrogen to the dryness and dissolved in $1 \mathrm{~mL}$ of the mobile phase, and filtered through syringe filter for analysis by DionexUltiMate 3000 liquid chromatography system (Thermo Scientific, Germany). Chromatograms were generated at $450 \mathrm{~nm}$ and $470 \mathrm{~nm}$ and carotenoids were identified and quantified by comparing with appropriate standards, and expressed as $\mu \mathrm{g} / \mathrm{g}$ of dry weight (DW).

Tocopherols $(\alpha-, \quad \gamma+\beta$ and $\gamma)$ were extracted using method described by Gliszczyńska-Świgło et al. (2007). Approximately $0.2 \mathrm{~g}$ of sample was mixed with 2-propanol, homogenized for $30 \mathrm{~min}$, and centrifugated at $3000 \mathrm{rpm}$ for $5 \mathrm{~min}$. After filtration, an aliquot of the supernatant was injeted to DionexUltiMate 3000 liquid chromatography system. The wave lengths for excitation and emission were at $290 \mathrm{~nm}$ and $325 \mathrm{~nm}$. Identification and quantification of the tocopherols content were done by comparison to the corresponding standards, and expressed in $\mu \mathrm{g} / \mathrm{g}$ of dry weight.

Analysis of variance according to a complete randomized block design was performed separately for all tested traits, and where main effect was significant $(\mathrm{p} \leq$ 0.05 ), least significant difference (LSD) was used to compare means. All analyses were accomplished using M-STAT-C package (Bricker, 1989). The correlations were determined by Pearson's correlation analysis. The calculation of correlation coefficients was done in Microsoft Excel.

Table 1. Average, minimum and maximum value of examined traits in maize landraces

Tabela 1. Prosečne, minimalne i maksimalne vrednosti ispitivanih svojstava kod populacija kukuruza

\begin{tabular}{lrrrr}
\hline Trait & \multicolumn{1}{c}{ Mean } & \multicolumn{1}{c}{ Min } & \multicolumn{1}{c}{ Max } & Cv (\%) \\
\hline Plant height (cm) & 216.73 & 128.50 & 270.75 & 6.03 \\
Ear height (cm) & 98.22 & 49.75 & 147.75 & 9.06 \\
Number of leaves above ear & 6.14 & 4.85 & 8.50 & 4.71 \\
Leaf length (cm) & 84.46 & 61.40 & 103.55 & 3.52 \\
Leaf width (cm) & 9.78 & 7.32 & 12.10 & 6.66 \\
Ear length (cm) & 15.54 & 10.10 & 20.05 & 4.33 \\
Number of rows per ear & 13.18 & 10.80 & 15.50 & 3.98 \\
Number of kernels per row & 30.51 & 21.83 & 38.10 & 3.42 \\
Grain yield per plant (g) & 51.98 & 29.48 & 112.76 & 18.60 \\
\hline
\end{tabular}




\section{Results and discussion}

Maize landraces represent natural variability, both, in agronomically important traits, and also in micronutrients, which have decreased during the breeding of modern high yielding hybrids. For the present study, we have chosen local landraces, collected in the former Yugoslavia territory, and landraces from abroad, with predominantly orange color and flint type of the kernel (Mladenović Drinić et al., 2016). Coefficient of variation for morphological traits was between $3.42 \%$ (number of kernels per row) and 9.06\% (ear height), (Table 1). Correlations between all morphological traits were significant, except interrelations with number of kernels per row (data not shown).

Maize exhibits great natural variation considering carotenoids and tocopherol contents in the kernels. Generally, two classes of carotenoids, carotens and xantophylls are responsible for the color of maize kernel, and their concentration is influenced by genetic and environmental factors. Provitamin A carotenoids ( $\beta$-cryptoxantin, $\alpha$-and $\beta$-carotene) usualy represent $10-20 \%$, whereas zeaxantin and lutein are dominant carotenoids with 30 $50 \%$ of total content in maize grain (OrtizMonasterio et al., 2007).

In the present study, $\beta$-carotene content varied from 0 (white kernel) to $7.95 \mu \mathrm{gg}^{-1}$ DW, with the average content of $2.87 \mu \mathrm{gg}$ ${ }^{1}$ DW. Out of all samples, 17 landraces had $\beta$-carotene content bigger than $2 \mu \mathrm{gg}^{-1} \mathrm{DW}$ (Table 2). Significant variability was detected for lutein and zeaxantin content, e.g. from 0 to 15.49 and $40.86 \mu \mathrm{gg}^{-1} \mathrm{DW}$, respectively. In general, biofortification comprehend increasing in nutrient content in food (Pfleffer and McClafferty, 2007). During last decades, maize is getting more importance because of $\beta$-carotene, precursor of vitamin A in cereals
(Welch, 2002). However, larger quantities of xantophylls (lutein and zeaxantin) in maize kernel are of less importance (Kuhnen et al., 2009). These carotenoids are with wellknown antioxidant activity, but they are nonprovitamin A carotenoids. Maize kernels with intense yellow and orange color reflect increased concentration of xantophylls (Rivera and Canela, 2012). In our study, the strongest correlation for kernel color was obtained with zeaxantine content $(\mathrm{r}=0.590 * * *)$, and weaker, but significant with $\beta$-carotene content $\left(\mathrm{r}=0.398^{*}\right)$. However, higher level of zeaxantyne was correlated with increased concentration of $\beta$-carotene $\left(\mathrm{r}=0.566^{* *}\right)$, (Table 3.). Similar relation was obtained between color and $\beta$-carotene, and zeaxantin content, respectively $(\mathrm{r}=0.36 ; \mathrm{r}=0.21$ ), (Harjes et al., 2008).

Considering previous studies maize grain color depends on double bonds and the various functional groups in the carotenoid molecule, and could not be directly connected with carotenoid content. However, chosen accessions were with dark yellow and orange grain color, and it could be expected that they have higher concentrations of $\beta$-carotene.

As it was previously shown (Combs and Combs, 1985), the most abundant form of tocopherols in maize kernels were $\gamma+\beta$. The content varies from 13.05 to $37.27 \mu \mathrm{gg}$ 1 DW (Table 4). Increased $\alpha$-tocopherol is commercially desirable because of its higher anti-oxidant activity than $\gamma$-tocopherol (Rocheford et al., 2002). Examined landraces showed increased level of $\alpha$-tocopherol (from 1.04 to $8.43 \mu \mathrm{gg}^{-1} \mathrm{DW}$ ), with noticeable higher content in introduced populations. The landraces number 1 and 12 had the highest content of $\gamma+\beta$, as well as $\alpha$-tocopherol. However, within introduced landraces, the highest $\alpha$-tocopherol content in kernel was in 
Table 2. Kernel content of $\alpha$-, $\beta+\gamma$-, $\delta$-tocopherol (in $\mu g g^{-1} \mathrm{DW}$ ) in 29 maize landraces Tabela 2. Sadržaj $\alpha$-, $\beta+\gamma$-, $\delta$-tokoferola u zrnu (upg $g^{-1}$ suve mase) kod 29 populacija kukuruza

\begin{tabular}{|c|c|c|c|}
\hline Landraces & $\alpha$-tocopherol & $\beta+\gamma$-tocopherol & $\delta$-tocopherol \\
\hline 1 & $7.90^{\mathrm{ab}}$ & 31.33bc & $2.21 \mathrm{~cd}$ \\
\hline 2 & $3.11 \mathrm{k}$ & $28.69 \mathrm{cde}$ & $6.00 \mathrm{a}$ \\
\hline 3 & 4.37fghi & 22.02ghijkl & $1.91 \mathrm{fg}$ \\
\hline 4 & $3.41 \mathrm{ijk}$ & 22.98fghij & $1.49 \mathrm{jk}$ \\
\hline 5 & $4.63 \mathrm{efg}$ & 24.29efgh & $1.63 i j$ \\
\hline 6 & $1.57 \mathrm{mn}$ & $30.57 \mathrm{bcd}$ & $4.38 \mathrm{~b}$ \\
\hline 7 & $1.04 \mathrm{n}$ & 19.15ijklmn & $1.57 \mathrm{ijk}$ \\
\hline 8 & $3.07 \mathrm{k}$ & $34.40 \mathrm{ab}$ & $2.00 \mathrm{ef}$ \\
\hline 9 & 3.57hijk & 13.260 & $0.97 \mathrm{pqr}$ \\
\hline 10 & 4.17fghij & $25.74 \mathrm{defg}$ & $1.72 \mathrm{hi}$ \\
\hline 11 & $6.97 \mathrm{bc}$ & 30.06bcd & $1.47 \mathrm{kl}$ \\
\hline 12 & $7.71 \mathrm{ab}$ & $37.27 \mathrm{a}$ & $2.08 \mathrm{de}$ \\
\hline 13 & $6.53 \mathrm{~cd}$ & $15.55 \mathrm{mno}$ & $1.32 \mathrm{~lm}$ \\
\hline 14 & $6.24 \mathrm{~cd}$ & 23.13fghi & $1.88 \mathrm{fg}$ \\
\hline 15 & $4.51 \mathrm{fgh}$ & 19.99hijklm & 1.1 nop \\
\hline 16 & $1.99 \mathrm{mn}$ & 21.84ghijkl & $1.29 \mathrm{~m}$ \\
\hline 17 & $3.02 \mathrm{kl}$ & 17.90klmno & $1.00 \mathrm{pq}$ \\
\hline 18 & 3.76ghijk & 14.23 no & $0.93 q r$ \\
\hline 19 & $4.94 \mathrm{ef}$ & 23.97efghi & $1.79 \mathrm{gh}$ \\
\hline 20 & $4.72 \mathrm{efg}$ & $17.491 \mathrm{mno}$ & $0.83 \mathrm{rs}$ \\
\hline 21 & 4.70efg & $15.87 \mathrm{mno}$ & $1.72 \mathrm{hi}$ \\
\hline 22 & $1.51 \mathrm{mn}$ & 24.11efghi & $2.36 c$ \\
\hline 23 & $3.16 \mathrm{k}$ & 22.70ghijk & $2.26 c$ \\
\hline 24 & $5.57 \mathrm{de}$ & $28.00 \mathrm{cdef}$ & $2.07 \mathrm{de}$ \\
\hline 25 & $8.09 \mathrm{a}$ & $15.10 \mathrm{mno}$ & $1.04 \mathrm{opq}$ \\
\hline 26 & $3.21 \mathrm{jk}$ & 19.63hijklm & $1.25 \mathrm{mn}$ \\
\hline 27 & $8.40 \mathrm{a}$ & 17.94jklmno & $1.19 \mathrm{mno}$ \\
\hline 28 & $2.041 \mathrm{~m}$ & $17.73 \mathrm{klmno}$ & $1.05 \mathrm{opq}$ \\
\hline 29 & 4.77 & $14.54 \mathrm{no}$ & $0.75 \mathrm{~s}$ \\
\hline LSD & 0.98 & 5.08 & 0.159 \\
\hline
\end{tabular}

LSD (last significant difference) between means using t tests where $p>0.05$ 
Table 3. Association of grain quality traits of 29 maize landraces

Tabela 3. Međuzavisnost svojstava kvaliteta zrna kod 29 populacija kukuruza

\begin{tabular}{lcclcccc}
\hline & Kcol & $\delta$-toco. & $\gamma+\beta$ toco. & $\alpha$-toco. & lutein & zeaxantin & $\beta$-caroten \\
\hline Ktype & $0.563^{* *}$ & 0.072 & -0.040 & -0.228 & $-0.489^{* *}$ & 0.216 & 0.072 \\
Kcol & & -0.085 & -0.074 & -0.097 & -0.288 & $0.590^{* * *}$ & 0.398 \\
$\delta$-toco. & & & $0.559^{* *}$ & -0.212 & -0.142 & -0.231 & $-0.381^{*}$ \\
$\gamma+\beta$ toco. & & & 0.149 & -0.030 & -0.319 & -0.229 \\
$\alpha$-toco. & & & & 0.267 & 0.075 & $0.500^{* *}$ \\
lutein & & & & & -0.082 & 0.040 \\
zeaxantin & & & & & & & $0.566^{* *}$ \\
\hline
\end{tabular}

$*, * *$ and $* * *$ means significant at $p<0,05 ; 0,01$ and 0,001, respectively

populations 27 and 25 , which have relatively low content of $\gamma+\beta$ tocopherols in maize grain. The level of most important, $\alpha$-tocopherol is about $20 \%$ of total tocopherols in maize (Rocheford, 2002), and its higher levels can be obtained through either utilization of existing natural variation or by genetic engineering (Hallauer and Miranda, 1995). In our study, the only significant correlation was obtain between $\alpha$-and $\delta$-tocopherol $\left(\mathrm{r}=0.559^{* *}\right)$. In the study of maize populations, correlations between $\alpha$ - and $\gamma$-tocopherol was low and negative $\left(\mathrm{r}=-0.140^{* *}\right.$, Galili et al., 2002). All the other correlations between carotenoids and tocopherols, except between $\beta$-caroten and zeaxantin, $\left(\mathrm{r}=0.566^{* *}\right)$ were non significant (Table 3 ), like in the study of maize sweet and dent lines (Kurilich and Juvik, 1999). One of possible conclusion is that content of these micronutriens are under independent regulation and that increased level could be bred simultaneously.

Although the information about nutritional content of maize kernel is scarce, inbreds and populations are increasingly used for biofortification. Obtained results from present study will contribute to growing interest for exploitation of maize landraces with increased nutritional properties due to society demands.

\section{Conclusions}

The landraces could be chosen to create a pool for breeding for increased content of $\beta$-carotene and $\alpha$-tocopherol, on the basis of obtained results:

17 landraces were separated according to $\beta$-carotene content higher than $2 \mu \mathrm{gg}^{-1} \mathrm{DW}$; out of them, landraces number $10,13,18$ and 19 showed no significant difference among each other;

16 landraces have $\alpha$-tocopherol content higher than $4 \mu \mathrm{gg}^{-1} \mathrm{DW}$; out of them landraces number 3, 5, 15, 19, 20, 21, 24 and 29 were with similar content.

For simultaneously increased content of $\beta$-carotene and $\alpha$-tocopherol, pool for breeding purposes could be created from 11 landraces 3, 5, 10, 12, 13, 15, 19, 20, 24, 25 and 27. 


\section{KERNEL MICRONUTRIENT CONTENT IN MAIZE LANDRACES 39-48}

Table 4. Kernel content of $\beta$-carotene, lutein and zeaxantin (in $\mu g g^{-1} \mathrm{DW}$ ) in 29 maize landraces

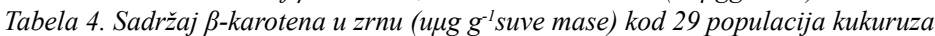

\begin{tabular}{|c|c|c|c|}
\hline Landraces & $\beta$-carotene & lutein & zeaxantin \\
\hline 1 & $1,59^{\mathrm{jk}}$ & $9,43^{\mathrm{b}}$ & $7,05^{\mathrm{jk}}$ \\
\hline 2 & $1,09^{\mathrm{lm}}$ & $1,50^{\mathrm{jk}}$ & $8,96^{\text {hij }}$ \\
\hline 3 & $3,38^{\mathrm{f}}$ & $9,09^{\mathrm{b}}$ & $10,61^{\mathrm{gh}}$ \\
\hline 4 & $2,34^{\mathrm{hi}}$ & $7,23^{c}$ & $9,475^{\text {hij }}$ \\
\hline 5 & $3,01^{\mathrm{fg}}$ & $9,14^{\mathrm{b}}$ & $30,05^{\mathrm{b}}$ \\
\hline 6 & $0,55^{\mathrm{n}}$ & $5,69^{\mathrm{de}}$ & $4,141^{\mathrm{mn}}$ \\
\hline 7 & $0,68^{\mathrm{mn}}$ & $3,80^{\mathrm{fg}}$ & $1,51^{\mathrm{no}}$ \\
\hline 8 & $1,06^{\mathrm{lm}}$ & $2,91^{\text {ghi }}$ & $1,89^{\mathrm{mno}}$ \\
\hline 9 & $4,39^{\text {de }}$ & $9,99^{\mathrm{b}}$ & $19,86^{\mathrm{d}}$ \\
\hline 10 & $4,77^{\mathrm{cd}}$ & $7,61^{\mathrm{c}}$ & $15,19^{\mathrm{ef}}$ \\
\hline 11 & $1,31^{\mathrm{kl}}$ & $7,03^{c}$ & $3,13 \mathrm{I}^{\mathrm{mn}}$ \\
\hline 12 & $4,07^{\mathrm{e}}$ & $7,35^{\mathrm{c}}$ & $1,87^{\mathrm{mno}}$ \\
\hline 13 & $4,79^{\mathrm{cd}}$ & $15,49^{\mathrm{a}}$ & $10,38^{\mathrm{ghi}}$ \\
\hline 14 & $0,74^{\mathrm{mn}}$ & $5,25^{\mathrm{e}}$ & $2,281^{\mathrm{mno}}$ \\
\hline 15 & $2,04^{\mathrm{ij}}$ & $14,48^{\mathrm{a}}$ & $7,86^{\mathrm{ij}}$ \\
\hline 16 & $2,61^{\mathrm{gh}}$ & $2,78^{\text {ghij }}$ & $14,02^{\mathrm{ef}}$ \\
\hline 17 & $2,25^{\mathrm{hi}}$ & $4,36^{\mathrm{ef}}$ & $4,26^{\mathrm{lm}}$ \\
\hline 18 & $4,78^{\mathrm{cd}}$ & $1,45^{\mathrm{jk}}$ & $40,86^{\mathrm{a}}$ \\
\hline 19 & $4,83^{\mathrm{cd}}$ & $1,60^{\mathrm{ijk}}$ & $13,03^{\mathrm{fg}}$ \\
\hline 20 & $4,49^{\mathrm{de}}$ & $4,71^{\mathrm{ef}}$ & $7,16^{\mathrm{jk}}$ \\
\hline 21 & $1,43^{\mathrm{kl}}$ & $6,8^{\mathrm{cd}}$ & $4,59^{\mathrm{kl}}$ \\
\hline 22 & $0,00^{\circ}$ & $0,0^{1}$ & $0,0^{\circ}$ \\
\hline 23 & $0,57^{\mathrm{n}}$ & $2,95^{\mathrm{gh}}$ & $2,05^{\mathrm{Imno}}$ \\
\hline 24 & $5,40^{\mathrm{b}}$ & $1,93^{\text {hijk }}$ & $16,47^{\mathrm{e}}$ \\
\hline 25 & $7,95^{\mathrm{a}}$ & $1,24^{\mathrm{kl}}$ & $22,75^{c}$ \\
\hline 26 & $5,09^{\mathrm{bc}}$ & $1,74^{\mathrm{hijk}}$ & $10,40^{\text {ghi }}$ \\
\hline 27 & $5,52^{\mathrm{b}}$ & $2,49^{\text {ghijk }}$ & $4,48^{\mathrm{klm}}$ \\
\hline 28 & $1,49^{\mathrm{kl}}$ & $2,19^{\text {hijk }}$ & $7,14^{\mathrm{jk}}$ \\
\hline 29 & $1,14^{\mathrm{klm}}$ & $2,19^{\text {hijk }}$ & $9,28^{\text {hij }}$ \\
\hline LSD & 0,48 & 1,337 & 2,692 \\
\hline
\end{tabular}

LSD (last significant difference) between means using t tests where $p=0.05$ 


\section{Acknowledgement}

This work was supported by Ministry of Education, Science and Technological Development, Republic of Serbia, through the project TR31068-Improvement of maize and soybean traits by molecular and conventional breeding.

\section{References}

Adom KK and Liu RH (2002): Antioxidant activity of grains. Journal of Agricultural and Food Chemistry, 50: 6182-6187.

Bellon MR and J van Etten (2013): Climate change and on-farm conservation ofcrop landraces in centres of diversity. In: M. Jackson, B. Ford-Lloyd, M. L. Parry(ed): Plant genetic resources and climate change, New York, NY: CABI Publishing.

Combs SB, Combs GF (1985): Varietal Differences in the Vitamin E Content of Corn. J. Agric. Food Chem., 33: 815817.

Drinić Mladenović S, Mesarović J, Anđelković V, Kovačević D, Babić V (2016): Maize populations as a source of micronutrient improvement. Book of Proceedings: 895-900.VII International Scientific Agriculture Symposium "Agrosym 2016", Jahorina, October 06.-09., 2016., Bosnia and Herzegovina.

Galili G, Galili S, Lewinsohn E, Tadmore Y (2002): Genetic, molecular and genomic approaches to improve value of plant foods and feeds. Crit. Rev. Plant Sci., 21: 167-204.

Gliszczyńska-Świgło A, Sikorska E, Khmelinskii I, Sikorski M (2007): Tocopherol content in edible plant oils. Polish journal of food and nutritional sciences, 574 (A): 157-161.

Hallauer AR and Miranda FJB (1995): Quantitative genetics in Maize
Breeding. $2^{\text {nded. Iowa State University }}$ Press, Ames, IA, USA.

Harjes EC, Rocheford TR, Bai L, Brutnell TP, Kandianis CB, Sowinski SG, Stapleton AE, Vallabhaneni R, Williams M, Wurttzell ET, Yan J, Buckler ES (2008): Natural genetic variation in lycopene epsilon cyclase tapped for maize biofortification. Science, 319: 330-333.

Kurilich AC and Juvik JA (1999): Quantification of Carotenoid and Tocopherol Antioxidants in Zea mays. J. Agric. Food Chem., 47: 1948-1955

Kuhnen S, Lemos PMM, Campestrini LH, Ogliari JB, Dias PF, Maraschin M (2011): Antiangiogenic properties of carotenoids: a potential role of maize as functional food. Journal of Functional Foods, 1: 284-290.

Ortiz-Monasterio I, Palacios-Rojas N, Meng E, Pixley K, Trethowan R, Pena RJ (2007): Enhancing the mineral and vitamin content of wheat and maize through plant breeding. Journal of Cereal Science, 46: 293-307.

Pixley K, Rojas NP, Babu R, Mutale R, Surles R, Simpungwe E (2013): Biofortification of maize with provitamin A carotenoids. In: S.A.Tanumihardjo (ed): Carotenoids and Human Helth,Nutrition and Helth. Springer Science+Business Media, New York, 271-292.

Pfleffer WH and Mc Clafferty B (2007): Harvest Plus: breeding crops for better nutrition. Crop Science, 47: 88-105.

Rivera S and Canela R (2012): Influence of sample processing on the analysis of carotenoids in maize. Molecules, 17: 11255-11268.

Rocheford TR, Wong JC, Egesel CO, Lambert RJ (2002): Enhancement of Vitamin E Levels in Corn. J Amer Coll Nutr, 
21:191-198.

Sattler SE, Gilliland LU, MagallanesLundback M, Pollard M, Della Penna D (2004): Vitamin E is essential for seed longevity and for preventing lipid peroxidation during germination. Plant Cell, 16:1419-1432.

Traber MG, Atkinson J (2007): Vitamin E, antioxidant and nothing more. Free Rad Biol \& Med, 43(1): 4-15.
Welch RM (2002): Breeding strategies for biofortified staple foods to reduce micronutrient malnutrition globally. The Journal of Nutritional Biochemistry, 132: 495-499.

Wurtzel ET (2004): Genomics, genetics, and biochemistry of maize carotenoid biosynthesis. Recent Advances in Phytochemistry, 38: 85-110. 


\title{
EVALUACIJA MORFOLOŠKIH OSOBINA I MIKRONUTRIENATA ZRNA KOD POPULACIJA KUKURUZA
}

\author{
Violeta Andjelković, Jelena Mesarović, Mirjana Srebrić, Natalija Kravić, \\ Vojka Babić, Snežana Mladenović Drinić
}

\begin{abstract}
Sažetak
U odnosu na druge žitarice, zrno kukuruza sadrži visok nivo karotenoida i tokoferola. Od svih karotenoida $\beta$-karoten ima najveću aktivnost i smatra se najznačajnim u biofortifikacijskim programima oplemenjivanja žitarica. Ovo istraživanje je imalo za cilj da utvrdi razlike u morfološkim svojstvima, sadržaju tokoferola $(\alpha-, \beta+\gamma-, \delta$-), $\beta$-karotena, luteina i zeaksantina kod lokalnih i introdukovanih populacija kukuruza iz banke gena Instituta za kukuruz "ZemunPolje".

Sadržaj mikronutrienata je utvrđen primenom HPLC metode. Koeficijent varijacije za morfološka svojstva je bio manji od $10 \%$, osim za prinos zrna po biljci $(\mathrm{Cv}=18,6 \%)$. Sadržaj $\alpha$-tokoferola je bio u rasponu od $1,04-8,42 \mu \mathrm{g} \mathrm{g}^{-1}$ suve mase, a $\beta$-karotena od 0,26 to $7,95 \mu \mathrm{g}$ $\mathrm{g}^{-1}$ suve mase. $\delta$-tokoferol je bio u značajnoj korelaciji sa brojem zrna u redu ( $\left.\mathrm{r}=0,700^{* * *}\right)$, dok je $\beta+\gamma$-tokoferol bio u značajnoj negativnoj korelaciji sa visinom biljke i klipa(r=-0,601***; r=$\left.0,591^{* *}\right)$. Korelacije između morfoloških svojstava i $\alpha$-tokoferola bile su slabe i nesignifikantne.

Boja zrna je bila u značajnoj korelaciji sa sadržajem zeaksantina $\left(\mathrm{r}=0,590^{* * *}\right)$ i $\beta$-karotena $\left(\mathrm{r}=0,398^{*}\right)$. Za potrebe biofortifikacije "pool" od 11 populacija sa povećanim sadržajem i $\beta$-karotena i $\alpha$-tokoferola biće formiran na osnovu dobijenih rezultata.
\end{abstract}

Ključne reči: $\beta$-karoten, zrno, tokoferol, populacije, Zea mays L.

Primljen: 18.10 .2016$.

Prihvaćen: 6.12.2016. 